УДК 626.81/84:831.67

DOI https://doi.org/10.32851/tnv-tech.2021.3.13

\title{
ТЕОРЕТИКО-МЕТОДОЛОГІЧНІ ЗАСАДИ ФОРМУВАННЯ ЕКСПЕРТНИХ СИСТЕМ ЕФЕКТИВНОСТІ ЗРОШЕННЯ I ГОРИЗОНТАЛЬНОГО ДРЕНАЖУ
}

\author{
Морозов О.В. - доктор сільськогосподарських наук, профресор, \\ профресор кафедри гідротехнічного будівництва, водної інженерії \\ та водних технологій \\ Херсонського державного аграрно-економічного університету \\ ORCID ID: 0000-0002-5617-0813 \\ Іванів М.О. - кандидат сільськогосподарських наук, доцент, \\ в.о. завідувача кафедри рослинництва та агроінженерії \\ Херсонського державного аграрно-економічного університету \\ ORCID ID: 0000-0002-4793-6194 \\ Морозов В.В. - кандидат сільськогосподарських наук, професор, \\ профресор кафедри гідротехнічного будівництва, водної інженерії \\ та водних технологій \\ Херсонського державного аграрно-економічного університету \\ ORCID ID: 0000-0002-2594-883X
}

Козленко Є.В. - кандидат сільськогосподарських наук, докторант Інституту зрошуваного землеробства Національної академії аграрних наук України ORCID ID: 0000-0002-5617-081

У статті наведені узагальнені матеріали з теоретико-методологічного обтрунтування процесів і методів формування експертних систем, ш⿻о призначені для оиінки технічної та еколого-меліоративної ефективності закритого горизонтального дренажу на зрошуваних та прилеглих до них землях сухостепової зони України.

Закритий горизонтальний дренаж-складова гідротехнічної системи, яка є радикальним інженерним заходом, щчо забезпечує багаторічний захист зрошуваних та прилеглих до них земель у слабодренованій $і$ безстічній зонах від підтоплення, вторинного засолення та осолониювання грунтів. Аналіз сучасного стану наявних систем горизонтального дренажу свідчить про недостатню увагу до його експлуатації, а ті вибіркові дані про роботу дренажу, шзо збираються відповідними виробничими управліннями, не мають можливості об 'єктивно оцінити його технічну та еколого-меліоративну ефективність.

Стратегія зрошення і дренажу в Україні до 2030 року значною мірою спрямована на вирішення проблеми відтворення, реконструкиії і технічної модернізацї наявних систем горизонтального дренажу, проєктування, будівництва та ефективну експлуатацію дренажу на нових ділянках. Одним із найбільи актуальних питань є забезпечення ефективної роботи всіх систем закритого горизонтального дренажу, яке можливо реалізувати тільки на базі здійснення моніторингу ефективності дренажу. Сучасною теоретико-методологічною базою такого моніторингу повинні стати експертні системи ефективності горизонтального дренажу.

Для вирішення вищеназваних питань на кожній зрошуваній системі необхідне створення відповідних експертних систем, включно з, перш за все, базами даних і базами знань та комплексом спещіалізованих комп'ютерних програм для моделювання $і$ прогнозування процесів формування еколого-меліоративного режиму грунтів і ландшафтів на зрошуваних системах з дренажем.

Запропонований перелік досліджуваних показників для комплексної оцінки ефективності горизонтального дренажу та науково-методологічний підхід для вивчення, аналізу й очінки ефективності дренажу на дослідно-виробничих ділянках зрошення $і$ дренажу, які є типовими для відповідного зрошуваного масиву та можуть застосовуватися для 
постійного контролю ефективності горизонтального дренажу на звичайних виробничих зрошувальних ділянках.

Ключові слова: зрошення, горизонтальний дренаж, експертні системи, технічна та еколого-меліоративна ефективність дренажу.

Morozov O.V., Ivaniv M.O., Morozov V.V., Kozlenko Y.V. Theoretical and methodological bases of formation of expert systems of efficiency of irrigation and horizontal drainage

The article presents generalized materials on the theoretical and methodological substantiation of the processes and methods of formation of expert systems, which are designed to assess the technical and ecological-reclamation efficiency of closed horizontal drainage on irrigated lands of the dry steppe zone of Ukraine.

Closed horizontal drainage is a component of the hydraulic system, which is a radical engineering measure that provides long-term protection of irrigated lands in poorly drained and drainless areas from flooding, secondary salinization and alkalization of soils.

The strategy of irrigation and drainage in Ukraine un to 2030 is mainly aimed at solving the problem of reproduction, reconstruction and technical modernization of existing horizontal drainage systems, design, construction and efficient operation of drainage in new areas. One of the most topical issues of this problem is to ensure the effective operation of all closed horizontal drainage systems, which can be implemented only on the basis of monitoring the effectiveness of drainage. Expert systems of horizontal drainage efficiency should become a modern theoretical and methodological basis for this monitoring.

To solve the above problems on each irrigated system it is necessary to create appropriate expert systems, including primarily databases and knowledge bases and a set of specialized computer programs for modeling and forecasting the formation of ecological-reclamation mode of soils and landscapes on irrigated systems with drainage.

The study offers the list of indexes under study for the complex estimation of efficiency of horizontal drainage and scientific-methodological approach to studying, analyzing and estimating of efficiency on the research-production plots of irrigation and drainage which are typical for the corresponding irrigated area and can be applied to control of the work of drainage on usual industrial production plots.

Key words: irrigation, horizontal drainage, expert systems, technical and ecologicalreclamation efficiency of drainage.

Вступ. У реалізації Стратегії зрошення і дренажу в Україні до 2030 року [1] актуальним питанням є забезпечення ефективного функціонування гідромеліоративних систем (далі - ГМС), що включають зрошувальну і дренажну системи, що працюють у взаємодії і разом з природними умовами, в які вони вписані, складають цілісну ландшафтно-меліоративну систему (далі - ЛМС). Основним науково-методологічним інструментарієм постійного меліоративного контролю ефективності функціонування ГМС у сучасних умовах можуть стати відповідні експертні системи (далі - ЕС), які повною мірою будуть використовуватись фахівцями-експертами в процесі експертизи ефективності як проєктів, так і процесу експлуатації систем зрошення і дренажу.

Постановка проблеми. Актуальною проблемою підвищення ефективності цілісної системи зрошення і дренажу є необхідність відновлення та вдосконалення чинної системи моніторингу ефективності зрошення на тлі закритого горизонтального дренажу на безстічних і слабодренованих землях сухостепової зони України. Нинішня система контролю роботи горизонтального дренажу також не забезпечує об'єктивної оцінки його ефективності. Перспективним напрямом у вирішенні цієї проблеми є розробка і впровадження спеціалізованих експертних систем моніторингу ефективності горизонтального дренажу (у складі системи зрошення-дренаж), для формування яких необхідне теоретико-методологічне обгрунтування.

У статті наведені розробки з науково-методологічного обгрунтування принципів і методів формування експертної системи моніторингу ефективності горизонтального дренажу на зрошуваних ландшафтах. 
Враховуючи, що експертні системи створюються на базі наукових досліджень у відповідності галузі, важливу роль перш за все повинні відігравати мета і завдання досліджень, об’єкт і предмет дослідження.

Мета дослідження - розробити науково-методологічні засади формування експертної системи для оцінки ефективності закритого горизонтального дренажу на зрошуваних землях сухостепової зони України.

Основні завдання досліджень:

- проаналізувати сучасний стан оцінки ефективності функціонування горизонтального дренажу і запропонувати шляхи вдосконалення цього процесу у застосуванні експертної системи;

- розробити науково-методичні засади формування експертної системи для оцінки ефективності горизонтального дренажу і підготовки заходів щодо підвищення ефективності дренажу;

- запропонувати перелік показників і критеріїв оцінки ефективності функціонування горизонтального дренажу та шляхів організації моніторингу ефективності горизонтального дренажу.

Об'єкт дослідження - технічна система закритого горизонтального дренажу, що вписана в природно-технічну систему, яку в наших дослідженнях доцільно вважати ландшафтно-меліоративною системою.

Предмет дослідження - показники, за якими оцінюється ефективність горизонтального дренажу: технічний стан дренажної системи, дренажний стік, мінералізація та хімічний склад дренажних вод, рівень грунтових вод, еколого-меліоративний стан зрошуваних земель на ділянці, де функціонує горизонтальний дренаж, урожайність сільськогосподарських культур тощо.

Матеріали і методи дослідження. У статті використано узагальнення даних багаторічних наукових пошуків проблемної науково-дослідної лабораторії еколого-меліоративного моніторингу агроекосистем сухостепової зони імені професора Д.Г. Шапошникова Херсонського державного аграрного університету, матеріали Управління каналів Інгулецької зрошувальної системи, Снігурівської гідрогеолого-меліоративної партії.

Методи досліджень - системний аналіз і системний підхід до вивчення й управління функціонуванням закритого горизонтального дренажу як складної природно-технічної системи [4], методи польових і лабораторних досліджень показників технічної та еколого-меліоративної ефективності горизонтального дренажу, індукції, порівняння, метод непрямих визначень, історичний метод.

Аналіз останніх досліджень і публікацій. Дослідження ефективності закритого горизонтального дренажу в зоні зрошення висвітлені в публікаціях останніх років Д.П. Савчука, О.І. Харламова, І.В. Котиковича, В.В. Морозова, О.В. Морозова, Є.В. Козленка та інших науковців. [5-9]. У цих роботах головним чином приділяється увага питанням боротьби 3 негативними інженерно-геологічними явищами, підтопленням зрошуваних земель і населених пунктів, вторинному засоленню та деградації грунтів, а також регульованому використанню дренажних вод на звичайних і рисових зрошувальних системах. Особливої уваги заслуговує питання оцінки ефективності роботи горизонтального дренажу на слабодренованих і безстічних землях сухостепової зони України, що поливаються із закритої внутрішньогосподарської зрошувальної мережі.

Питання розробки і впровадження експертних систем для оцінки ефективності горизонтального дренажу, а також відповідних інженерно-меліоративних заходів у сучасних умовах водо- та землекористування залишаються актуальними, але не 
вивченими, а для формування і впровадження експертних систем необхідне теоретико-методологічне обгрунтування.

Виклад основного матеріалу досліджень. Багаторічні дослідження роботи закритого горизонтального дренажу, проведені на прикладі Інгулецької зрошувальної системи (далі - I3C), показали таке. 3 урахуванням того, що IЗС розташована на території двох областей - Миколаївської та Херсонської, контроль роботи дренажу і еколого-меліоративного стану здійснюється двома окремими організаціями Держводагентства України. На території Білозерського району Херсонської області це Басейнове управління водних ресурсів Нижнього Дніпра з відділом на базі колишньої Каховської гідрогеолого-меліоративної експедиції, а на території Вітовського та Жовтневого районів Миколаївської області контроль здійснюють Південно-Бузьке басейнове управління водних ресурсів та Снігурівська гідрогеолого-меліоративна партія.

Під час контролю роботи горизонтального дренажу названі виробничі організації аналізують такі показники: технічний стан колекторно-дренажної системи і дренажних насосних станцій, зокрема обсяги дренажного стоку, мінералізацію і хімічний склад дренажних вод, що здійснюється 2-3 рази на початку і в кінці вегетаційного періоду та іноді влітку. У сертифікованих лабораторіях басейнових управлінь виконуються відповідні хімічні аналізи, результати яких групуються у зведених таблицях за відповідними роками, додаються дані з обсягів дренажного стоку (тис. м $^{3}$ ), які визначаються замірами дренажного стоку в колекторно-дренажних колодязях, проведених об'ємним способом 2-3 рази на рік. Ці дані щорічно передаються на зберігання в архіви Басейнових управлінь, які підпорядковані Держводагентству України.

Важливо зазначити, що під час цих робіт не проводиться оцінка ефективності функціонування горизонтального дренажу як на окремих дренажах, ділянках, так i на Інгулецькому зрошуваному масиві загалом.

У рекомендаціях щодо покращення роботи дренажу мова може йти тільки про відновлення роботи дренажних насосних станцій або самовплинного скиду дренажних вод. У цих матеріалах відсутні дані про винос солей дренажними водами, зв'язок роботи горизонтального дренажу з такими показниками еколого-меліоративного стану зрошуваних та прилеглих до них земель, як рівень грунтових вод, вторинне засолення грунтів, грунтотворних порід зони аерації, мінералізацією та хімічним складом грунтових вод, основними елементами водного і сольового балансу, урожайністю сільськогосподарських культур.

Аналогічна картина спостерігається у контролі роботи горизонтального дренажу на всіх зрошувальних системах сухостепової зони: Каховській, Краснознам'янській, Північно-Кримській, Явкінській тощо. Водночас слід зазначити, що всі показники ефективності дренажу розглядаються окремо один від одного, контролюються різними організаціями, наводяться в різних звітних документах, не враховують вплив різних режимів зрошення і питомої водоподачі, практично не узагальнюються та повною мірою не використовуються для підвищення ефективності функціонування дренажу.

Таким чином, сучасна система контролю роботи горизонтального дренажу зрошуваних земель нині потребує радикального вдосконалення, що можливо тільки на основі розробки експертних систем «Горизонтальний дренаж: ефективність», які повинні бути сформовані на основі узагальнення результатів досліджень за всі роки роботи дренажу на кожній системі. Для цього також потрібен пошук і розробка відповідного науково-методологічного та методичного обгрунтування. 
У сучасному розвитку науки і техніки особливої уваги набувають технічні системи штучного інтелекту (далі - ШІ), що будуються на базі засобів обчислювальної техніки і призначені для сприйняття, обробки та зберігання інформації, а також формування оптимальних рішень з управління відповідними системами у різних ситуаціях їх розвитку. Досвід, накопичений у теоретичних та експлуатаційних дослідженнях систем штучного інтелекту, показує, що такі системи можуть ефективно застосовуватися в різних галузях діяльності людини. Однією з таких галузей є водне господарство, зокрема системи гідротехніки і гідромеліорації, в яких основними об'єктами досліджень є системи зрошення і дренажу.

Як формулюється в Словнику 3 кібернетики [10, с. 246]: «Розумність, інтелектуальність системи штучного інтелекту, як правило, оцінюється по аналогії 3 поведінкою фахівця-інженера в подібних ситуаціях. Це визначає включення в дослідження ШІ таких видів діяльності людини, як впізнавання, формування понять, міркування, прийняття оптимальних рішень, прогнозування, адаптація, обчислення тощо. Метою досліджень для побудови системи штучного інтелекту $\epsilon$ розробка моделей досліджуваних процесів та їх реалізація в системах ШІ. Дослідження різних видів інтелектуальної діяльності фахівця здійснюється шляхом аналізу і вирішення відповідних інженерно-технічних завдань».

У дослідженнях, спрямованих на підвищення ефективності систем зрошення і дренажу, найбільш доцільним з позиції застосування систем ШІ є підготовка і прийняття оптимальних рішень у різних ситуаціях в процесі управління цими системами [10], зокрема для оптимізації еколого-меліоративного режиму зрошуваних ландшафтів, грунтів і ландшафтно-меліоративних систем загалом, побудову систем навчання тощо.

Теоретичні питання створення ШІ включають такі аспекти: створення моделей інтелектуальних систем, засобів опису їх поведінки, функціонування, структури і властивостей, а також методів і засобів їх побудови. Окремий розділ теорії штучного інтелекту складають математичні методи рішення завдань відповідної галузі науки і техніки.

Успіхи в застосуванні штучного інтелекту можуть бути досягнуті за побудови формальних систем і дедуктивних процедур, придатних для автоматизованого планування доцільного у заданій системі умов і факторів формування відповідного об'єкта досліджень.

Одним з інтенсивно розроблюваних засобів ШІ є бази даних, бази знань та методи їх застосування в управлінні складними, зокрема й природно-технічними системами. Останнім часом одержали широкий розвиток експертні системи, які можуть ефективно застосовуватись і в системі еколого-агромеліоративного моніторингу зрошуваних земель.

«Експертною системою (ЕС, з англ. expert system) у загальному вигляді називається комп'ютерна система, яка спроможна частково замінити фахівця - експерта у вирішенні стандартної або невивченої проблемної ситуації. Найважливішою частиною експертної системи є бази знань (далі - БЗ) як моделі поведінки експертів у відповідній області знань із застосуванням процедур логічного висновку і прийняття рішень. Іншими словами, Б3 - сукупність факторів і правил логічного висновку в обраній предметній області діяльності людини» [2; 3]. Бази знань ЕС формуються на основі узагальнення науково-технічної літератури, публікацій, бази даних (далі - БД), які одержуються в результаті досліджень відповідних систем, у нашому випадку - горизонтального дренажу. 
Первинним призначенням баз даних є зберігання масивів інформації, але вони широко використовуються для збереження спеціалізованих, наприклад, інженерних, економічних, екологічних та інших даних і моделей. Об'єднання великої кількості даних в єдину базу створює умови для формування великої кількості інформації, наприклад, з усіх аспектів функціонування системи горизонтального дренажу в часі та просторі. Головною перевагою БД $є$ швидкість внесення та використання необхідної інформації. Завдяки спеціальним алгоритмам, які використовуються для баз даних, можна оперативно знаходити необхідні дані, доповнювати, моделювати та прогнозувати їх. Також у базі даних існує певний зв'язок інформації: зміна в одному ряду може спричиняти зміни в інших рядках - це допомагає працювати з інформацією простіше і швидше [3].

Системи управління базами даних (далі - СУБД) - це прикладні комп'ютерні програми, що призначені для створення, збереження та використання баз даних.

Прикладні комп'ютерні програми повинні забезпечувати формування і постійне накопичування баз даних за всіма показниками ефективності горизонтального дренажу з побудовою графіків динаміки цих показників. Формування баз знань здійснюється на основі узагальнення баз даних з відповідних показників, а також із результатів моделювання і прогнозування таких показників. Особливу увагу необхідно приділяти одержанню залежностей між досліджуваними показниками, наприклад:

- взаємозв'язку дренажного стоку та напору грунтових вод у середині міждренної відстані;

- взаємозв'язку дренажного стоку та складових водного балансу, що визначають сумарний приход води на ділянку дренажу за вегетаційний період та за рік (календарний та гідрологічний);

- взаємозв'язку мінералізації дренажних і грунтових вод;

- взаємозв'язку мінералізації і основних складових хімічного стану дренажних, грунтових і зрошувальних вод;

- динаміці засолення (загального і токсичного) грунтів, грунтотворних порід зони аерації, взаємозв'язку засолення з динамікою рівня грунтових вод та інфільтраційним живленням грунтових вод, що відображає наявність промивного поливного режиму на зрошуваних штучно дренованих землях;

- залежності засолення грунтів і грунтотворних порід зони аерації від мінералізації та хімічного складу зрошувальної води;

- залежності урожайності сільськогосподарських культур від всіх умов і факторів формування еколого - меліоративного режиму зрошуваних грунтів і ландшафтів на зрошуваних дренованих ділянках тощо.

Важливим $є$ такий аспект, як моделі гідрографу дренажного стоку, а також інтегральної кривої дренажного стоку впродовж року.

Визначення вищеназваних та інших залежностей відбувається методами моделювання. На основі визначених моделей прогнозується розвиток досліджуваних показників та грунтово-гідрогеологічних процесів. Методами аналізу і синтезу формуються бази знань з ефективності закритого горизонтального дренажу.

Детально всі роботи з формування баз даних і баз знань здійснюються на типових для зрошуваного масиву дослідно-виробничих ділянках (далі - ДВД) зрошення на фоні горизонтального дренажу. На інших виробничих ділянках дренажу здійснюється вибірковий контроль показників ефективності дренажу. Для застосування баз даних і баз знань, одержаних на ДВД, для розробки достовірних звітів з ефективності дренажу на виробничих ділянках розробляються відповідні алгоритми і комп'ютерні програми. 
Для визначення ефективності дренажу на виробничих ділянках розробляються і впроваджуються відповідні методи. У таблиці наведений алгоритм одержання даних для комплексної оцінки ефективності горизонтального дренажу за основним показником - дренажним стоком і хімічним складом дренажних вод. Заміри дренажного стоку та хімічні аналізи дренажних вод дають змогу спиратися як на фактичні дані, так і на непрямі та розрахункові показники, які необхідні в оцінці ефективності дренажу.

Таблиця 1

Алгоритм одержання розширених даних для комплексної оцінки ефективності закритого горизонтального дренажу за дренажним стоком і хімічним складом дренажних вод

\begin{tabular}{|c|c|c|}
\hline Вид показників & $\begin{array}{c}\text { Вимірювальні } \\
\text { показники }\end{array}$ & $\begin{array}{l}\text { Розрахункові та непрямі } \\
\text { показники ефективності }\end{array}$ \\
\hline \multirow[t]{4}{*}{ 1. Дренажний стік. } & \multirow[t]{2}{*}{ 1.1. Стік з дрен, л/с. } & $\begin{array}{l}\text { 1.1.1. Модуль дренажного стоку, } \\
\text { л/с з } 1 \text { га. }\end{array}$ \\
\hline & & 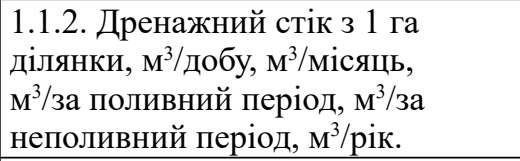 \\
\hline & \multirow{2}{*}{$\begin{array}{l}\text { 1.2. Рівень грунтових вод } \\
\text { у середині міждренної } \\
\text { відстані. }\end{array}$} & $\begin{array}{l}\text { 1.2.1. Напір над дреною в } \\
\text { середині міждренної відстані, м. }\end{array}$ \\
\hline & & $\begin{array}{l}\text { 1.2.2. Розрахунковий середній } \\
\text { рівень грунтових вод на площі } \\
\text { між дренами. }\end{array}$ \\
\hline \multirow{5}{*}{$\begin{array}{l}\text { 2. Мінералізація } \\
\text { та хімічний склад } \\
\text { дренажних вод }\end{array}$} & \multirow[t]{2}{*}{$\begin{array}{l}\text { 2.1.Мінералізація } \\
\text { дренажних вод, г/дм³. }\end{array}$} & $\begin{array}{l}\text { 2.1.1. Мінералізація грунтових вод, } \\
\text { г/дм³. }\end{array}$ \\
\hline & & $\begin{array}{l}\text { 2.2.1. Гідрохімічний склад } \\
\text { грунтових вод верхньої активної } \\
\text { товщі (8-10 м), з якої формується } \\
\text { дренажний стік. }\end{array}$ \\
\hline & \multirow{2}{*}{$\begin{array}{l}\text { 2.2. Гідрохімічний склад } \\
\text { дренажних вод }\left(\mathrm{CO}_{3}^{2-},\right. \\
\mathrm{HCO}_{3}^{-}, \mathrm{Cl}^{-}, \mathrm{SO}_{4}^{2-}, \mathrm{Ca}^{2+}, \\
\left.\mathrm{Mg}^{2+}, \mathrm{Na}^{+}+\mathrm{K}^{+}\right), \text {мг-екв} / \text { дм}^{3}, \\
\% \text {-екв } / \text { дм }^{3}, \text { мг/дм } 3 .\end{array}$} & $\begin{array}{l}\text { 2.2.1. Сумарний винос солей } 3 \\
\text { дренажним стоком, т/га за рік. }\end{array}$ \\
\hline & & $\begin{array}{l}\text { 2.2.2.Винос гіпотетичних солей, } \\
\text { т/га за рік }\end{array}$ \\
\hline & 2.3. pH дренажної води. & $\begin{array}{l}\text { Зв’язок } 3 \text { процесом осолонцювання } \\
\text { і деградації грунтів. }\end{array}$ \\
\hline
\end{tabular}

Одним із найважливіших питань оцінки і забезпечення ефективної роботи горизонтального дренажу є визначення критеріїв, які повинні забезпечуватися роботою дренажу у відповідній природно-кліматичній зоні. Такі критерії були визначені на основі багаторічних досліджень функціонування закритого горизонтального дренажу на безстічних і слабо дренованих землях в сухостеповій зоні України (О.В. Морозов, В.В. Морозов, С.В. Козленко, 2021) [5, с. 64-67] і доповнюються в даній роботі.

До критеріїв ефективності функціонування горизонтального дренажу належать: - технічний стан колекторно-дренажної мережі та дренажних насосних станцій; 
- модуль дренажного стоку (середньорічний, у вегетаційний та у невегетаційний періоди);

- рівень грунтових вод в середині міждренної відстані, а також величини напору грунтових вод над дреною, яка залежить зокрема і від відстані між дренами;

- швидкість спрацювання рівня грунтових вод (далі - РГВ) в середині міждренної відстані після підйому РГВ, пов'язаного з інтенсивним інфільтраційним живленням грунтових вод від атмосферних опадів і поливів;

- відношення річного дренажного стоку до водоподачі на ділянку горизонтального дренажу у вегетаційний період;

- відношення річного дренажного стоку до приходу сумарної кількості води на дренажну ділянку впродовж року (тут важливо враховувати як календарні роки, за якими здійснюється моніторинг кліматичних показників, так і гідрологічні роки: 31 квітня по 31 березня кожного року);

- зміни мінералізації та хімічного складу дренажних вод з урахуванням їх періодичної динаміки та процесів метаморфізму, еволюції, що відбувається в періоди функціонування дренажу 30-50 років і більше;

- зміни мінералізації та хімічного складу грунтових вод, особливо в активній зоні (8-10 м від їхньої поверхні, звідки формується дренажний стік та його хімічний склад);

- зміни загальної і токсичної засоленості грунту і грунтотворних порід у шарах 0-25 см, 25-50 см, 50-75 см, 75-100 см, 100-150 см, 150 см - до РГВ;

- зміни урожайності сільськогосподарських культур в їх тісній кореляції з режимом зрошення, режимом грунтових вод, засоленістю грунтів і грунтотворних порід зони аерації;

- відношення фактичної урожайності до проєктної;

- показник рівня використання меліорованих земель.

Оцінку ефективності закритого горизонтального дренажу на кожній дренажній ділянці зрошувальної системи необхідно планово проводити 2 рази на рік, на початку вегетаційного періоду (III декада березня) та в кінці вегетаційного періоду (II-III декада жовтня), за необхідності проводиться оцінка у вегетаційний період. Накопичення інформації про досліджувані показники ефективності дренажу відбувається у базі даних експертної системи, а розвиток їх динаміки відображається на відповідних графіках.

Особливості оцінювання ефективності функціонування кожної ділянки горизонтального дренажу полягають у такому:

- оцінка здійснюється за кожним показником методом порівняння значень фактичних показників з їх критеріями [5, с. 67] (критерії можуть уточнюватися в процесі функціонування і практичного використання експертної системи);

- обов'язково звертається увага на ті показники, які за попереднього оцінювання мали низьку та незадовільну ефективність; а також необхідно пересвідчитись, що показники, які мали високу та задовільну ефективність, не знизили цей рівень;

- основою методології оцінювання ефективності горизонтального дренажу $\epsilon$ системний цілісний підхід, який полягає в систематичному аналізі всіх аспектів впливу дренажу на еколого-меліоративний стан зрошуваних земель; це означає, що судження про рівень відповідальності кожного досліджуваного показника формулюється, беручи до уваги всю цілісність встановлених фактів з урахуванням їх взаємозв'язку і динаміки;

- варто визначити, наскільки неефективне значення кожного з показників впливає на загальну оцінку ефективності кожної системи горизонтального дренажу, 
тобто в процесі функціонування експертної системи визначається вагомість кожного з показників ефективності дренажу;

- експерти, які оцінюють ефективність кожної ділянки (системи) горизонтального дренажу, визначають у певному випадку, як виявлені недоліки за кожним показником окремо та в їхній сукупності впливають на функціонування дренажу в цілому, а також визначають реальні можливості, строки та економічні витрати для покращення ситуації на кожній ділянці і на зрошувальній системі в цілому;

- за кожною оцінкою ефективності функціонування горизонтального дренажу на зрошуваному масиві (мінімум 2 рази на рік) складається відповідний звіт з конкретними висновками і рекомендаціями;

- експертні системи оцінки ефективності горизонтального дренажу доцільно формувати для кожної зрошувальної системи (масиву), а для виконання цієї роботи можуть бути задіяні провідні науково-дослідні інститути, університети або відповідні наукові центри; на кожному етапі створення експертних систем необхідно видання тимчасових науково-методичних рекомендацій щодо формування цих систем, робочих груп експертів та відповідних баз даних і баз знань.

\section{Висновки і пропозиції.}

1. У реалізації Стратегії зрошення і дренажу в Україні до 2030 року значна увага приділяється питанням відновлення, реконструкції, модернізації та забезпеченню ефективної роботи дренажу в зоні зрошення, перш за все - горизонтального, як найбільш розповсюдженого і перспективного. Аналіз сучасного стану наявних систем горизонтального дренажу свідчить про недостатню увагу до його експлуатації, а ті вибіркові дані про роботу дренажу, що збираються відповідними виробничими управліннями, не мають можливості об'єктивно оцінити його технічну та еколого-меліоративну ефективність.

2. Для вирішення названих питань на кожній зрошуваній системі необхідне створення відповідних експертних систем ефективності дренажу, включаючи, перш за все, бази даних і бази знань та комплекс спеціалізованих комп'ютерних програм для моделювання і прогнозування процесів формування еколого-меліоративного режиму грунтів і ландшафтів на зрошуваних системах з горизонтальним дренажем.

3. Запропонований перелік досліджуваних показників для комплексної оцінки ефективності горизонтального дренажу та науково-методологічний підхід для вивчення, аналізу і оцінки ефективності дренажу на дослідно-виробничих ділянках зрошення і дренажу, які є типовими для відповідного зрошуваного масиву та можуть застосовуватися для постійного контролю ефективності горизонтального дренажу на звичайних виробничих зрошувальних ділянках.

\section{СПИСОК ВИКОРИСТАНОЇ ЛІТЕРАТУРИ:}

1. Стратегія зрошення та дренажу в Україні на період до 2030 року : схвалено розпорядженням Кабінету Міністрів України від 14 серпня 2019 року № 688-p. База даних «Законодавство Украӥни». URL: https://zakon.rada.gov.ua/ laws/show/688-2019-p\#Text

2. Експертна система. Вікіпедія - вільна енциклопедія. URL: https://uk.wikipedia. org/wiki/Експертна_система

3. Що таке база даних? Кафедра АПЕПС ТЕФ КПI ім. І. Сікорського. URL: http://apeps.kpi.ua/shco-take-basa-danykh

4. Морозов В.В. Основи системного аналізу в гідромеліорації : навч. посібник. Херсон : Вид-во ХДУ, 2008. 64 с.

5. Морозов О.В., Морозов В.В., Козленко С.В. Системний підхід у дослідженнях технічної ефективності закритого горизонтального дренажу. Таврійський нау- 
ковий вісник. Серія: технічні науки / Херсонський державний аграрно-економічний університет. Херсон : Видавничий дім «Гельветика», 2021. Вип. 2. С. 60-69.

6. Харламов O.I. Ефективність систематичного горизонтального дренажу на слабостічних та безстічних територіях зрошуваних масивів. Вісник аграрної науки. Київ : «Аграрна наука». 2019. № 1. С. 72-82.

7. Савчук Д.П., Харламов О.І., Котикович І.В. Ефективність закритого горизонтального дренажу на фоні зрошення ДМ «Фрегат». Меліораиія $і$ водне господарство. 2018. Вип. 1 (107). С. 30-36.

8. Савчук Д.П., Харламов О.І., Котикович І.В. Горизонтальний дренаж на фоні зрошення дощувальною машиною «Фрегат». Водне господарство України. 2019. № 1-2. С. $12-18$.

9. Козленко Є.В., Морозов О.В., Морозов В.В. Інгулецька зрошувальна система: стан, проблеми та перспективи розвитку : монографія / за ред. О.В. Морозова. Херсон : Айлант, 2020. 204 с.

10. Словарь по кибернетике : Св. 2000 ст. / Под ред. В.С. Михайлевича 2-е изд. Киев : Гл. ред. УСЭ им. М.П. Бажана, 1989. 751 с.

\section{REFERENCES:}

1. Stratehiia zroshennia ta drenazhu v Ukraini na period do 2030 roku [Irrigation and drainage strategy in Ukraine for the period up to 2030]: skhvaleno rozporiadzhenniam Kabinetu Ministriv Ukrainy vid 14.08.2019 r. № 688-r. URL: https://zakon.rada.gov.ua/ laws/show/688-2019-r\#Text [in Ukrainian].

2. Ekspertna systema [Expert system]. URL: https://uk.wikipedia.org/wiki/Eкcпертна_ система [in Ukrainian].

3. Shcho take baza danykh? [What is a database?]. URL: http://apeps.kpi.ua/shcotake-basa-danykh [in Ukrainian].

4. Morozov, V.V. (2008). Osnovy systemnoho analizu v hidromelioratsii: navch. Posibnyk [Fundamentals of systems analysis in land reclamation: textbook. manual]. Kherson : Vyd-vo KhDU [in Ukrainian].

5. Morozov, O.V., Morozov, V.V., \& Kozlenko, Ye.V. (2021). Systemnyi pidkhid u doslidzhenniakh tekhnichnoi efektyvnosti zakrytoho horyzontalnoho drenazhu [System approach in researches of technical efficiency of the closed horizontal drainage]. Tavriiskyi naukovyi visnyk. Seriia: tekhnichni nauky - Taurian Scientific Bulletin. Series: technical sciences. 2. 60-69 [in Ukrainian].

6. Kharlamov, O.I. (2019). Efektyvnist systematychnoho horyzontalnoho drenazhu na slabostichnykh ta bezstichnykh terytoriiakh zroshuvanykh masyviv [Efficiency of systematic horizontal drainage in weakly drained and non-drained areas of irrigated massifs]. Visnyk ahrarnoi nauky - Bulletin of Agricultural Science. Kyiv: "Ahrarna nauka", 1, 72-82 [in Ukrainian].

7. Savchuk, D.P., Kharlamov, O.I. \& Kotykovych, I.V. (2018). Efektyvnist zakrytoho horyzontalnoho drenazhu na foni zroshennia DM "Frehat" [The efficiency of closed horizontal drainage against the background of irrigation DM "Frigate"]. Melioratsiia $i$ vodne hospodarstvo - Land reclamation and water management, 1 (107), 30-36 [in Ukrainian].

8. Savchuk, D.P., Kharlamov, O.I. \& Kotykovych, I.V. (2019). Horyzontalnyi drenazh na foni zroshennia doshchuvalnoiu mashynoiu "Frehat" [Horizontal drainage on the background of irrigation sprinkler "Frigate"]. Vodne hospodarstvo Ukrainy Water management of Ukraine, 1-2, 12-18 [in Ukrainian].

9. Kozlenko, Ye.V., Morozov, O.V., \& Morozov, V.V. (2020). Inhuletska zroshuvalna systema: stan, problemy ta perspektyvy rozvytku : monohrafiia [Ingulets irrigation system: state, problems and prospects of development: monograph]. Kherson : Ailant [in Ukrainian].

10. Slovar po kibernetike : Sv. 2000 st. [Dictionary of Cybernetics: St. 2000 Art.] / Pod red. V.S. Mihaylevicha (1989). 2-e izd. KiYiv: Gl. red. USE im. M.P. Bazhaka [in Russian]. 